NBER WORKING PAPER SERIES

INTERNATIONAL ASPECTS OF DIVIDEND RELIEF

Charles E. McLure, Jr.

Working Paper No. 317

NATIONAL BUREAU OF ECONOMIC RESEARCH

1050 Massachusetts Avenue

Cambridge MA 02138

February 1979

The research reported here is related to NBER programs of research on Business Taxation and Finance and on International Studies and to the Bureau's special project on Capital Formation. Any opinions expressed are those of the author and not those of the National Bureau of Economic Research. 


\section{International Aspects of Dividend Relief}

\section{SUMMARY}

This paper examines international aspects of the provision of relief from the double taxation of dividends that now occurs under the "classical" American system of taxing corporate income to both corporations and shareholders. It begins with reviews of the recent American debate over integration and dividend relief, the systems of dividend relief now being used in Europe, and commonly accepted standards for judging international tax policy. These standards are employed in the appraisal of existing arrangements in Europe, possible alternative systems for international taxation in a world of dividend relief, and, using the European-American situation as an example, relations between countries with dividend relief and those with classical systems.

Charles E. McLure, Ir. National Bureau of Economic Research 1050 Massachusetts Avenue Cambridge, MA 02138 $617 / 868-3906$ 


\section{INTERNATIONAL ASPECTS OF DIVIDEND RELIEF \\ by \\ CHARLES E. MCLURE, JR. \\ National Bureau of Economic Research* \\ and \\ Rice University}

I. INTRODUCTION

Few topics in fiscal affairs have received the concentrated attention that has been devoted to integration and dividend relief over the past five years. ${ }^{1}$ During that time, the United Kingdom reversed its earier decision to abandon an imputation system in favor of the classical system, Germany considered seriously adoption of complete integration before converting its split-rate system to a hybrid form of complete dividend relief which employs both a split rate and a shareholder credit, Italy adopted complete dividend relief, and the United States flirted casually with integration and more seriously with dividend relief. 2 Though the United States is hardly alone in its adherance to the classical system, its position may become increasingly uncomfortable. 3

The purpose of this paper is to examine international aspects of dividend relief. Until recently these have received relatively little attention in American discussions of integration and dividend relief. They have, of course, been more important in the European debate because of the relatively greater reliance on foreign trade and international capital flows in Europe. A substantial part of the paper is devoted to discussion of European approaches to these problems. A working acquaintance with systems of dividend relief employed in European countries now or in the recent past is essential for at least two reasons. First, if one is familiar 
with such systems, he does not need to "reinvent the wheel." Instead, he can copy the best features of other systems and avoid the worst. Second, any country considering adopting dividend relief will naturally want to design a system that can be coordinated with those in other countries. Moreover, through careful design it may be possible to increase the country's bargaining position in international tax negotiations.

In order to allow full attention to be devoted to international considerations, conventional arguments for and against integration and dividend relief based primarily on domestic considerations are largely ignored, as are the important administrative difficulties that would be encountered in implementing integration or dividend relief in a closed economy.$^{4}$ Administrative considerations in the international sphere which would condition any choice between methods of integration or dividend relief are, however, considered.

The paper begins with a short summary of the American debate over integration and dividend relief. Section III contains a description of systems of dividend relief used in selected European countries now or in the recent past and that proposed in the 1975 draft directive for harmonization of company taxation in the E.E.C. Section. IV describes commonly accepted objectives of international tax policy that provide standards against which to appraise alternative tax systems. Having been formulated in a world of classical systems, they may need to be rethought in a world of dividend relief. Section $V$ appraises various approaches to dividend relief from an international point of view. Section VI deals with the somewhat more limited question of dividend relief in the context of economic relations within the 
(3)

European common market. Section VII considers the effects of dividend relief from the perspective of European countries dealing with the United States, which still uses a classical system. But this section is of more general relevance because in considering dividend relief the United States would confront other countries with classical systems, as well as those with dividend relief (for which Section $V$ is more relevant).

\section{THE U.S. POLICY DISCUSSION}

American interest in integration and dividend relief seems to have had its genesis in at least three influences. The earliest, but not necessarily the strongest, is the academic infatuation with integration, based on the Haig-Simons definition of income for tax purposes and reinforced by the analysis and conclusions of the Royal Commission on Taxation in Canada (1966). Academic advocates of integration have ordinarily stressed its distributional advantages and its neutrality toward corporate financial policy and the allocation of economic resources. Interestingly, they have seldom mentioned the second, and perhaps the most influential, argument made for dividend relief in the recent debate: stimulus to capital formation. Those who favor dividend relief as a way to encourage saving and investment implicitly base their argument upon the questionable assumption that revenues lost in dividend relief would not be made up in a way that maintained the progressivity of the income tax. A final impetus to American interest in dividend relief was European activity in the field. As was true earier when the countries of Europe where adopting the tax on value added, some American observers seem to have believed that the United 
(4)

States should follow the European path. Presumably this desire for emulation was based at least in part on perceived economic advantages; but part of the attraction may also have been the mystique of the relatively unknown. The United States has, of course, not adopted either integration or dividend relief. It has, however, come closer to doing so than at any time during the four decades since it repealed the tax on undistributed profits levied briefly during the $1930^{\prime}$ s. In 1975 the Secretary of the Treasury, William Simon (1975), presented Congress with a proposal for the complete elimination of double taxation of dividends similar to that now in effect in Germany. Subsequently the Treasury Department issued Blueprints for Basic Tax Reform (1977), a white paper which argued that full integration was both desirable and administratively feasible and presented dividend relief as an attractive second best solution if full integration were rejected. Coming at the end of the Ford administration, Blueprints resulted in no direct political action. It did, however, add important weight to the academic arguments for integration and stimulated considerable further discussion. There was a widespread expectation that President Carter, goaded in part by the perceived need to do something for capital formation, would propose a system of partial dividend relief in his 1977 tax message. When Carter did not do so, Chairman Al Ullman of the House Ways and Means Committee (1978) introduced legislation which was said to be patterned closely after the treasury proposals rejected by the White House. The 1978 tax act did not contain dividend relief. And given that it did contain important provisions reducing the taxation of long-term capital gains, pressure for fiscal stimulus to capital formation 
and interest in integration and dividend relief may have subsided.

It is interesting to speculate on why efforts to obtain integration or dividend relief were not successful. Perceived administrative difficulties mast surely be one reason. Difficulties of implementing full integration had been known for at least 30 years ${ }^{5}$ and the Canadian Royal Commission on Taxation and Blueprints for Basic Tax Reform did not fully dispel fears that full integration could not be administered. Of course, dividend relief is a reasonable fallback position for advocates of integration, and European experience provides evidence that it could be implemented. 6 But the existence of tax preferences creates administrative problems and raises policy issues that had been only imperfectly perceived in earlier discussions, including those of the Royal Commission on Taxation, in Blueprints, and perhaps in Europe. 7 Decisions must be made on whether tax preferences are to be passed through to shareholders or nullified when preference income is distributed. Moreover, regardless of which decision is made, it is necessary to have stacking rules (at least implicit in the law) for the determination of the presumed order in which income is paid from fully taxed and various types of preference income. 8 Some ways of treating preference income are easier to administer than others; these are not, unfortunately, the ones for which the most compelling case can be made on grounds of public policy. And, in any event, feelings run high about the appropriate way to treat tax preferences under dividend relief. Finally, international flows of dividends add an additional layer of complexity to the administration of dividend relief, especially when combined with tax preferences. 
A second reason dividend relief did not get strong support is the uncertainty about many of its supposed economic effects. The expectations some adrocates had of a strong stimulus to saving and investment have been said to be unrealistic, the allocational advantages of integration have been questioned, effects on corporate financial policy (debtequity structure and dividend pay-out rates) are uncertain, and the distributional implications of dividend relief are thought by many to be inequitable. Since economists have been unable to speak with anything approaching unanimity on the economic effects of dividend relief, noneconomists have not rushed to adopt such a radical departure from traditional tax policy

Tax reform is, of course, not determined by academic considerations of administrative feasibility or analysis of economic effects; it is, rather, the outcome of conflicting political interests. But in few areas have the cross-currents of interest been as complicated as in the debate over integration and dividend relief.9 Not only do liberal economists, labor, and public interest groups line up on opposite sides of the issue from businessmen, as is so often the case. In addition, investors may view the matter quite diferently from corporate managers and these two groups may split farther depending on the form of dividend relief adopted, the treatment of tax preferences, the financial structure of firms and industries, the income level of shareholders, and fiscal arrangements in the international sphere. Moreover, tax-exempt organizations have an unusually important stake in the debate. All these potential conflicts are, of course, magnified (or at least maddled) by the existence of the ... 
administrative difficulties and uncertainties of economic effects mentioned above. Given this, it is hardly surprising that dividend relief has no strong and influential allies and that those seeking to use the tax system to stimulate capital formation have returned to more traditional approaches such as the preferential treatment of long-term capital gains.

III. ALTERNATIVE EUROPEAN APPROACHES TO DIVIDEND RELIEF

This section describes briefly the systems of dividend relief now being used in France, Germany, and the United Kingdom, the split-rate system used in Germany until 1977, and the approach to dividend relief contained in the 1975 draft directive of the Commission of the European Communities.10 Only the basic structure of the systems is given; primary emphasis is devoted to description of the taxation of international flows of dividend income. This, of course, involves taxation of a) dividends paid by domestic firms to foreign shareholders and b) taxation of dividends received from abroad by domestic shareholders. Because the two cannot be treated in isolation, withholding taxes collected on dividends paid to foreigners, as well as corporate taxes, are considered briefly.

\section{A. Germany (Post 1976) 11}

Germany is the only member of the European Common Market to provide rull relief from double taxation of dividends. It does so by employing a hybrid system which combines a split rate with a shareholder credit. In particular, the basic corporate tax rate is 56 percent. So far as corporate income is retained, this is a final tax. If, however, such income is distributed, the corporation receives a tax credit equal to 20 percent of the gross income, so that the net corporate tax on distributed earnings is only 36 percent. The shareholder grosses up his cash dividend and 
takes credit for the 36 percent corporate tax imputed to him. If dividends are paid from tax-preferred income the corporation must pay enough supplementary tax to bring the total tax rate paid at the corporate level on such income to 36 percent. In this sense, tax preferences are nullified if preference income is distributed. But the presumptive rules for the stacking of tax preferences are such that preference income is deemed to be the last to be distributed and preferences tend to be preserved.

The imputation credit is available only to German shareholders in domestic corporations. Thus German individuals who hold shares in foreign corporations are not allowed to take advantage of imputation credits on dividends received from abroad. The same is true of corporations making portfolio investments abroad and receiving dividends. Dividends received from abroad enter the tax base of both individuals and corporations making portfolio investments outside Germany, but without gross-up and credit for either foreign or domestic taxes. Credit is, however, allowed for foreign withholding taxes.

Profits of foreign branches and dividends received by German parent corporations from foreign subsidiaries are either tax-exempt under tax treaties or are taxable, but eligible for foreign corporate tax credit against the German tax. But Germany does not recognize the foreign corporate tax for purposes of calculating imputation credits. Rather, if foreign-source income that has not been subject to German tax is distributed, the German parent firm must pay a supplementary tax just as if it had distributed preference income. That is, the exemption of foreign source income and foreign tax credits are useful only to the extent that 
foreign income is not distributed. Foreign source income, like preference income, is assumed to be distributed only after all fully taxed domestic income has been distributed. These provisions create an important incentive for German firms (given their dividend payout policies) to have the proper mix of fully taxed and tax preference income and of foreign and domestic income in order to avoid liability for the supplementary tax and can therefore stimulate industrial concentration.

In that the corporate rate is reduced to 36 per cent on distributed earnings, dividend relief extends to that degree to all shareholders in German firms. But the additional relief provided by the imputation credit is available only to German shareholders; it does not extend to foreign shareholders, who must look to their countries of residence for relief.12 The United States, for example, would allow American firms with direct investment in German firms foreign tax credit for the unrelieved portion of the German corporate tax on distributed earnings as well as for German withholding tax. ${ }^{13}$ Individual shareholders and corporate portfolio investors resident in the United States would obtain no such relief, except for the credit for withholding tax. Rather, they would be taxed on their net dividends from Germany without credit from either Germany or the United States for corporate taxes paid on distributed corporate earnings.

In summary, Germany does not extend the imputation credit to either German investors in foreign firms or foreign investors in German firms. Nor does it show any inclination to do so. It does, however, as noted above, allow some benefit to foreign investors in Germany through the 
partial use of the split rate. (The parallel question of using the split-rate approach to provide relief to German shareholders in foreign firms is essentially meaningless.) Finally, in tax treaties negotiated before its 1977 adoption of full dividend relief, Germany obtained from several countries the nonreciprocal privilege of using a 25 per cent withholding rate on dividends so long as the differential in its two rates of corporate tax was at least 20 per cent. 14 Whether these treaties are valid under the new system is open to debate.

\section{B. France}

France levies a 50 percent corporation income tax but allows a shareholder credit equal to half the corporate tax paid on dividends. When preference income is distributed, a supplementary tax equal to the amount of the shareholder credit, called a précompte mobilier (or simply précompte); is levied. Thus, as in the German system, tax preferences are nullified if preference income is distributed; but again preference income is assumed, in general, to be distributed after fully taxed income. 15

Like Germany, France does not provide imputation credits to domestic investors in foreign corporations. Individuals and corporate portfolio investors pay tax on net dividends received from abroad, with no relief from double taxation (except for withholding taxes). Foreign-source income from direct investment is tax-exempt to the French parent. But as in Germany, such exempt foreign-source income is treated like preference income and subjected to the précompte if distributed.

Under French law the imputation credit is not automatically available 
to foreign investors in French firms. Several French treaties do, however, provide that the shareholder credit is available to shareholders in treaty countries who are taxable on French dividends in their country of residence and do not benefit from foreign tax credits for the French corporate tax. In practice this means that foreign individual shareholders and corporate portfolio investors are allowed the French imputation credit in treaty countries, but foreign direct investors are not.

C. United Kingdom

Since returning to the imputation system in 1973 the United Kingdom has provided relief from approximately half the double taxation of dividends. (Relief is currently $33 / 67$ of the corporate income tax.) A key administrative feature of the British system is the advance corporation tax or ACT. Any time a British firm pays a dividend, it must pay ACT at a rate equal to the rate at which the imputation credit will be allowed. If dividends are paid from taxable income, the ACT is merely credited against the firm's corporate tax. If, however, preference income is distributed, the ACT serves much the same purpose as the French and German précompte. That is, it insures that shareholder credit is not allowed for taxes not paid. But unlike those systems, under the British system it is not necessary to have explicit rules in order to provide that preference income is, in effect, presumed to be distributed after taxable income.

As in France and Germany, British shareholders are not allowed imputation credits on dividends received from abroad. Moreover, as in Germany, taxes paid to foreign countries by foreign subsidiaries of British firms are ignored in application of the imputation credit. The 
British parent receives a foreign tax credit for corporate taxes paid abroad, but the credit is allowed only against the so-called "mainstream corporate tax" (the net corporate tax liability after deduction of ACT); credit cannot be taken against that part of the corporate tax offset by ACT. Thus, as in the case of preference income, the ACT serves a purpose similar to that of the précompte.

British legislation allows the imputation credit only to domestic shareholders, but under double taxation treaties the credit has been granted to foreign portfolio investors in the United Kingdom. Unlike other countries, the United Kingdom has recently shown a reluctant willingness to extend through treaties an imputation credit to foreign corporate direct investors in the United Kingdom equal to one half the credit available to domestic investors.

D. Germany (Pre-1977)

Though the predominant form of dividend relief in Europe is the imputation approach, there are good reasons for believing that an alternative approach is superior on at least some grounds. This approach involves allowing corporations a deduction for dividends paid or, what is equivalent, applying a different rate to retained and distributed corporatesource income. Though Germany retains a split rate in conjunction with its imputation credit system, a better example of this alternative approach is the system used in Germany before 1977. Under that system a tax of 15 percent was levied on income used to pay dividends but retained income was subject to a rate of 51 percent. 16 
Dividend relief provided through the split-rate system automatically extends to foreign shareholders in domestic firms. Germany was, however, as mentioned above, able partially to ameliorate this disadvantage (and avoid the Auslaendereffekt mentioned in footnote 14 above) by negotiating nonreciprocal withholding rates with some of its treaty partners. Dissatisfaction with the automaticity of the relief provided to foreigners and American recalcitrance against more general use of nonreciprocal withholding rates were among the reasons for the German shift to primary reliance on the imputation approach as a means of providing dividend relief.

The split-rate system does not lend itself to the mitigation of double taxation of dividends received from abroad. Dividends on foreign portfolio investments were therefore taxed to German shareholders, with no relief from the foreign corporate tax. (The lower rate of tax was, of course, applied to redistributed earnings of corporate portfolio investors.) Dividends from foreign subsidiaries were ordinarily exempt; in such a case the lower rate of tax was not applied to earnings redistributed by the parent. Where not exempt under treaty, dividends on foreign direct investment were fully taxed to German parents, though the double tax burden would be reduced by foreign tax credit.

E. The E. E. C. Draft Directive

The twists and turns taken by proposals for harmonizing company taxes in the European Economic Community are rather incredible. 17 The Neumark Committee proposed that harmonization be based on a split-rate approach. Then van den Tempel, placing heavy weight on international considerations, 
proposed that member countries employ a "classical system" (and perhaps coined the term in the process). Most recently, the Commission of the European Communities based its proposal for harmonization on the imputation approach. Given that this last proposal has not been accepted, one can only guess what will be proposed next. It seems worthwhile, however, to summarize and appraise the approach recommended in the 1975 draft directive.

The draft directive can be described as patterned closely after the French approach to dividend relief. That is, it provides that all members of the European Economic Community would levy corporate income taxes at rates varying from 45 to 55 percent and that between 45 and 55 percent of the corporate tax burden on income distributed to shareholders would be removed through the use of a gross-up and credit. A précompte or advance corporation tax would be used t) prevent shareholders from taking credit for taxes not paid at the corporate level. Rules similar to those employed in France would be used to determine the presumptive order of sources of income from which dividends are paid for purposes of determining liability for précompte.

Under the scheme for dividend relief proposed in the draft directive the imputation credit would be based on the tax rate paid in the source country. This would be achieved by having the distributing company provide individual and corporate portfolio shareholders with vouchers stating the amount of tax credit attached to dividends received. The shareholder would submit this voucher with his tax return in his country of residence in order to claim credit. The fiscal authority of the 
shareholder's state of residence would collect from the treasury of the country of residence of the corporation paying dividends the amount indicated on vouchers for which it had given shareholders credit.

Under the draft directive parent firms receiving dividends from subsidiaries would not pay tax on such dividends; nor would they be able to claim imputation credit for corporate taxes paid by the subsidiary. As under other European imputation schemes currently in existence, distribution of tax-free income would ordinarily trigger liability for précompte or ACT. But when tax-free dividends received from subsidiaries were redistributed by the parent firm, the imputation credit "attached to" such dividends could be used to offset the parent's précompte or ACT. Of course, the parent company's shareholders would take the normal shareholder credit that accompanies dividends. As a result, the source country would obtain revenues from taxes levied on income retained by the subsidiary and on income distributed to the parent but retained there. But through a "clearing house" arrangement similar to that described above for portfolio dividends, it would bear the fiscal cost of integrating its tax into the imputation system of the country of residence of the parent.18

IV. OBJECTIVES OF INTERNATIONAL TAX POLICY

Economists often appraise fiscal relations on the basis of equity and neutrality. Though complicated enough in a closed economy context, application of these concepts is particularly difficult in the international sphere. This section describes several norms by which international fiscal relations can be judged. In addition, two concepts which are more or less 
unique to the international area are described. Finally, ease of compliance and administration is taken to be an important goal, through it is seldom discussed explicitly.

Economists commonly place economic neutrality high on their list of objectives for tax policy, because if certain stringent conditions are met a neutral tax system can be expected to result in the maximization of welfare. 19 of course, in the international arena when one discusses maximization of welfare, it is necessary to decide whose welfare is to "count" in the maximization. Maximization of world economic welfare (sometimes called worldwide efficiency) can be achieved when taxes do not distort the allocation of capital between countries, that is, when taxes exhibit capital-export neutrality. Under a classical system, capitalexport neutrality is usually said to be achieved either if the source country exempts corporate income from tax or if the country of residence of shareholders allows a foreign tax credit for corporate taxes paid to other countries. 20 In either event foreign-source income must be taxed by the residence country as it is earned, rather than merely when repatriated, if capital-export neutrality is to be achieved. Analyzing capital-export neutrality from the perspective of a classical system is basically inconsistent with the intellectual foundation of integration, under which the corporation is seen only as a conduit through which income passes to its ultimate recipients, the shareholders of the corporation. Thus in what follows capital-export neutrality is judged from an integrationist viewpoint. That is, aggregate corporate and personal liabilities are considered in determining whether foreign and 
domestic investments are taxed equally.

The welfare of a capital exporting country is maximized if the total return to the country, including tax revenue, is independent of where investment is made. In a classical system such a condition, often referred to as national efficiency, is said to be achieved if the residence country allows deduction of foreign taxes in calculating taxable income. Because capital-export neutrality involves equal net (after-tax) returns in all countries and national efficiency requires equal gross returns, the two principles are generally inconsistent. Capital-import neutrality is also generally inconsistent with integration and dividend relief that extends to foreign-source income.

Capital-import neutrality occurs if all capital invested in the same country is taxed identically. While this concept appeals to many businessmen, it has little attraction from the point of view of welfare maximization. In a sense, it is the opposite of capital-export neutrality. It can be achieved in a classical system if capital importing nations allow credit for taxes paid in residence countries or if capital exporting countries exempt foreign-source income. It, too, is inconsistent with integration and dividend relief.

Tax equity among persons involves questions of both the equality of taxation of given types of income at a given income level and systematic differences in tax rates levied across income levels. If horizontal interpersonal equity is defined only in terms of taxes levied by the taxpayer's country of residence (national equity), it is governed by the same considerations as is national efficiency. If, on the other hand, 
equity is defined in terms of taxes imposed by foreign countries, as well as the taxpayer's country of residence (international equity), it is governed by the same factors as capital-export neutrality. In either event, interpersonal equity need not be discussed further.

In addition to questions of interpersonal equity, and perhaps more important for the present discussion, are those of intercountry equity. These involve international division of income, including the division of tax revenues between national treasuries. 21 Though questions of the division of revenues among source countries may be as important as those of the distribution of revenues between countries of source and residence, we concentrate on the latter. The definition of this type of international fiscal equity depends upon several factors, including relative levels of per capita income and levels and types of public services. If, for example, one country provided substantial benefits to corporations but another did not, it would seem appropriate that the first should receive a relatively larger share of revenues from taxes on corporate income than the second. Similarly, most would feel that some degree of redistribution from rich to poor countries might be justified. Moreover, it can be argued that countries with substantial natural resources have a right to revenues from exploitation of such resources. Finally, if one country is a heavy net debtor and the other an equally heavy net creditor the distribution of tax revenues will depend crucially on the split of tax revenues between countries of source and residence.

Two important principles guiding tax treaty negotiations have been nondiscrimination and reciprocity. Under the first of these, host 
countries cannot discriminate in the taxation of domestic and foreign firms. The second requires that withholding rates should be "mirror images" of those applied by treaty partners. Taken together, these two conventions place countries using split rates at a severe disadvantage relative to those with classical systems. In the extreme case a country with a split-rate system of full dividend relief might collect only a 15 percent withholding tax on income distributed to American shareholders whereas the United States would collect the 46 percent corporate income tax 8.nd a 15 percent withholding tax on the gross distribution from the net income of 54. Whether these rules, which have developed in a world of classical tax systems, are appropriate in a world of dividend relief is hotly debated. Advocates of "effective reciprocity" argue that the total (corporate and withholding) tax burden levied on corporate income in the source country should be the basis for determining whether reciprocity is realized. 22

V. INTERNATIONAL APPRAISAL OF ARRANGEMENTS FOR DIVIDEND RELIEF 23 If we ignore full integration as being administratively infeasible and treat the split-rate and dividend-paid deduction systems as equivalent, we can imagine three approaches to the taxation of corporate-source income: a classical system, a split-rate regime, and an imputation approach, and six alternative combinations of fiscal systems between two trading partners (classical with classical, classical with imputation, etc.). Moreover, international investment in corporations can be implemented in at least four distinct ways: individual portfolio investment, corporate portfolio investment, corporate direct investment in foreign sub- 
sidiaries, and corporate direct investment in foreign branches. To attempt to examine systematically the tax treatment of each type of investment for each of the pairs of tax systems would be unmanageable, even if we were to ignore international differences in definitions of income, the treatment of tax preferences, and the degree of dividend relief. In what follows we therefore limit consideration primarily to individual portfolio investment in foreign shares and corporate direct investment in foreign subsidiaries. Morover, we devote primary attention to a comparison of two means of providing dividend relief employed in both nations: a split-rate system and an imputation approach. Subsequently problems created by the coexistance of systems of dividend relief and a classical system are considered briefly in Section VII.

One principle is absolutely clear. Dividend relief mast be based upon taxes collected in the country of source, rather than on the tax rate in the country of residence of shareholders, if capital-export neutrality is to be achieved. If it is not, relief will generally be either too great or too small, and exactly correct only by accident. This being the case, foreign investment in high-tax countries would be discouraged and that in low-tax countries would be stimulated artificially; in either event, capital export neutrality would not be achieved. As explained below, administrative considerations suggest that relief should be provided initially by the source country in the case of portfolio investors; for direct investment relief provided by the country of residence of the parent may be more appropriate. Which country bears the fiscal cost of dividend relief could, it seems, be a separate question. 
A. Portfolio Investment

Except in a very simple world without tax preferences, it would be cumbersome, and perhaps impossible, for residence countries to provide imputation credits based on taxes paid to source countries, without assistance from source countries. While the source country's statutory rate could be used by the residence country to calculate gross-up and credit in the absence of tax preferences, its use generally produces neither exact passthrough of preferences nor exact nullification of preferences. Nor can effective rates generally be used satisfactorily to nullify preferences. Only if a prêcompte is levied on distributed preference income will gross-up and credit based on the statutory rate result in washout of preferences. And to achieve pass-through of preferences, taxable income and exempt income must be reported separately, with only the former being subject to gross-up and credit. Moreover, tax credits must be reported separately so the shareholder can utilize them on his personal return. It is generally not possible to provide this information to shareholders accurately on a timely basis. (See McLure, 1978 and forthcoming, 1979, Chapter 4.)

The first questions, then, are whether preferences are to be passed through or nullified, the order in which preference and taxable income is assumed to be distributed, and which country is to make these decisions. In most cases it seems that the source country is in command. It determines whether or not to nullify preferences when it either levies a précompte or does not, and it would be difficult for the residence country to levy a prêcompte or use a variable-rate gross-up and credit based on source-country 
taxes. Moreover, since the distributing corporation is under the fiscal control of the source country, there seems to be no way the residence country could apply any stacking rules besides those of the source country. Similarly, if the source country does not require separate reporting of taxable income, exempt income, and credits, there is no way the residence country could pass through source-country credits, and trying to allow residence-country credits in such a case seems ridiculous. In short, the treatment of preferences must be determined by the source country.

Dividend relief based on source-country taxation is provided automatically by the dividend-paid deduction and split-rate systems. It could be achieved, though not so easily, if the source country provided imputation credits to foreign shareholders. One potentially useful approach would be that incorporated in the E.E.C. draft directive. That is, the country of residence of portfolio shareholders would allow credits for foreign corporate taxes paid based on vouchers issued by the foreign firm; it would then be reimbursed by the source country for amounts shown on the vouchers. Because it would stand to suffer the revenue loss entailed by falsified vouchers, the source country would have the incentive, as well as being in a better position, to scrutinize vouchers issued to shareholders by domestic firms. (It might even be thought worthwhile for the source-country fiscal authorities to certify the validity of vouchers in advance.)

Under such an approach the proper treatment of tax preferences becomes an interesting issue. In the absence of preferences complete dividend relief based on source-country taxes would result in capital-export 
neutrality, at least so far as distributed income is concerned. 24 But if tax preferences existed, the achievement of capital-export neutrality would depend on the treatment of preference income.25 In particular, if both countries allowed identical preferences and stacked them in the same way, but one country passed preferences through and the other washed them out, capital-export neutrality would not generally be achieved.26 Similarly, if both countries treated preference income deemed to be distributed identically, but had different stacking rules, capital-export neutrality would generally be violated. If, for example, both countries passed preferences through, less tax would be paid on dividend income originating in the country that stacks preferences first. If, on the other hand, preferences were washed out in both countries, taxation of dividends would be independent of the the stacking rules applied. But in both these cases retained earnings would be taxed differently in the two countries. 27 Finally, if whatever tax preferences existed were treated Identically in the two countries, but different preferences were allowed in the two countries, capital-export neutrality would generally be destroyed, and the arguments above apply a fortiori if all the potential differences mentioned above exist simultaneously.

It might be thought that this problem arises because foreign and domestic investors are treated identically by the source country, whereas capital-export neutrality requires that treatment be equal across domestic investors. It might appear adequate for the achievement of capital-export neutrality, for example, to pass preferences through to domestic shareholders but wash them out on distributions to foreigners. 
But besides being difficult to administer and blatantly discriminatory, such an approach would win only half of the battle; it would also be necessary to pass the same preferences through to domestic shareholders in foreign firms - a clearly nonsensical idea. This makes it clear that tax preferences allowed domestic investors to stimulate domestic saving are consistent with capital-export neutrality, whereas preferences to stimulate domestic investment are not. Given the prevalence of tax preferences intended to stimulate investment, the prospects for a system which is truly neutral with regard to capital export look bleak. To the extent that preferences are stacked last and washed out on distribution, as they commonly are in Europe, the interference with capital-export neutrality in the taxation of dividends may be rather minimal. But differences in taxation of retained preference income are potentially quite non-neutral.

Two issues remain to be discussed: partial dividend relief and the division of the fiscal cost of dividend relief. To the extent that relief is only partial, because a deduction is allowed for only part of dividends, because the split-rate applied to distributed income is not zero, or because the gross-up and credit is less than the corporate tax attributed to dividends, the income taxes are not integrated for distributed earnings. Capital-export neutrality generally will not be realized, even for distributed earnings, if corporate tax rates or the extent of dividend relief differ across countries. This is discussed further in section VI.

If portfolio investment is roughly balanced between countries and rates of return and corporate tax rates are comparable across countries, 
it makes relatively little difference whether the source or residence country provides dividend relief. If, however, investment is not balanced it can be expected that capital-importing countries would object to an arrangement under which they provided dividend relief, as under the scheme outlined above, and bore its fiscal cost. Thus whether the source country reimbursed the residence country completely for credits claimed on vouchers originating in the source country would seem to be a reasonable topic for negotiation. Certainly in fiscal relations with developing countries it might be deemed appropriate that developed countries should bear a relatively large share of the fiscal cost as source countries, but not a correspondingly small share as residence countries. To the extent that dividend relief is partial, this discussion would apply only to the extent that "integration" is achieved. On the part of dividends subject to double taxation, as well as on retained earnings, the source country would obtain all revenue from the corporate tax.

\section{B. Direct Investment}

Where direct investment through subsidiaries is concerned, the proper solution is not nearly so clear as in the case of portfolio investment. Suppose that both source and residence countries have split-rate or dividend-paid deduction systems. If the subsidiary's earnings are not taxed to the parent until they are distributed to it, the subsidiary's retained earnings bear tax at the rate prevailing in the source country. Dividends paid to the parent would be taxed only at the rates applicable in the country of residence of the parent. Earnings distributed by the parent would not be taxed at the corporate level, but would bear tax at the 
marginal rate of individual shareholders. Income retained by the parent would be taxed as such in the parent's country of residence. Though at first glance this solution seems reasonable enough, further examination reveals a serious flaw. 28 Suppose that the foreign subsidiary in this example is owned by a parent (or first-level subsidiary) chartered in a tax haven country. In such a case income distributed by the subsidiary and retained by the parent would go tax-free and we would have in accentuated form the "Auslaendereffekt" familiar from previous experience with the old German split-rate system. The same problem could occur if both countries employed the imputation system and the source country provided the imputation credits for tax paid by the subsidiary. Among closely associated countries, such as those of the European Common Market, an approach such as that proposed for direct investment under the E.E.C. draft directive might provide a workable solution, and such an approach might even be followed in bilateral tax treaties with other countries. But, as will be noted more fully in Section VI, this approach may not be workable if either degrees of dividend relief or corporate tax rates are not equal between two countries. Thus an alternative solution may need to be found, at least for relations outside the E.E.C.

One possible solution under the imputation approach would be for source countries to differentiate between direct investment through subsidiaries and portfolio investment, with the burden of providing dividend relief being left to the country of residence of the parent in the former case. This result could be achieved if a) imputation credits otherwise 
provided by the source country were denied foreign direct investors and b) the residence country allowed credit for the corporation income tax of the source country, without nullifying the credit when foreign source income was distributed. In the case of wholly-owned subsidiaries denial of the preferential rate for dividends paid to parents in a split-rate system would be the equivalent of provision (a); where subsidiaries are less than wholly owned the denial of the benefit of the split rate would presumably be shared by other stockholders in the subsidiary. Its effects could, in principle, be duplicated by a special withholding tax on distributions to parent firms. 29

The denial of imputation credits to foreign direct investors is, of course, standard. But the equivalent denial of the preferential rate on dividends paid abroad, or the application of special withholding taxes on such dividends, conflicting as it does with the principle of reciprocity, has been fought bitterly, especially by the United States, and is not common. Nor have countries of residence of parent firms been willing to integrate foreign corporate taxes into their own individual income taxes. Rather, they have used the précompte to reverse foreign tax credits on foreign-source income redistributed by parents.

Under the scheme outlined above, relief from double taxation of dividends, though based on tax paid in the source country, would be provided by the residence country. This has important implications for the division of revenues between source and residence countries; as in the case of portfolio investment, international arrangements for the sharing of fiscal costs might be in order. 
In the absence of tax preferences the approach described above would result in capital-export neutrality, at least for distributed earning. In a more realistic case, it would not. Tax preferences would be available to the parent firm so far as domestic income was retained; for distributed earnings domestic preferences could be passed through to shareholders or nullified, but the latter approach seems more likely.

In the absence of special provisions that seem to be politically unlikely, the approach outlined earlier would result in tax preferences available in the source country being washed out to the extent that preference income was distributed by the foreign subsidiary to the parent firm.30 (To the extent that the source country followed common European practice, this would be of little consequence; preferences are ordinarily washed out via a précompte in the source country when distributed.). Thus, leaving aside differences in the basic corporate tax rates applied to retained corporate source income and differences in the availability of preferences in the two countries, we see that preferences would remain intact on income retained by the source-country subsidiary and on domestic income retained by the parent firm. They would be nullified on income distributed by the subsidiary, including that retained by the parent, and probably on domestic income distributed by the parent. It appears unlikely that capital-export neutrality would be achieved. As was noted above, so long as preferences are based on investment, rather than on saving, capital export neutrality cannot generally be achieved. 31 
VI. HARMONIZATION IN THE COMMON MARKET

If all European countries had similar rates of corporate tax and similar degrees of dividend relief, the methods of dealing with dividends crossing international borders proposed in the E.E.C. draft directive would be quite reasonable. It is consistent with the principle announced in the previous section that dividend relief must be based on taxes paid in the source country. (But if all corporate tax rates were similar, adherence to this principle would be relatively unimportant.) Moreover, the approach suggested seems to be a sensible means of dealing with the problem posed by dividends paid to parents by subsidiaries.

If, however, either corporate tax rates or degrees of dividend relief differ significantly between member countries, the approach suggested in the draft directive is severely deficient. That this is true is evidenced by Germany's refusal to approve the draft directive. Germany, as noted above, is the only member country of the E. E. C. which currently provides full relief from double taxation of dividends.

\section{A. Portfolio investment}

The problem posed by unequal corporate tax rates or degrees of dividend relief is easily seen. Suppose first that corporate rates are equal, but that different degrees of dividend relief are allowed. 32 In such a case the country with the more fully integrated tax system would be providing more relief for foreign shareholders in domestic firms than its own shareholders in foreign firms were receiving. Besides the revenue cost to the country providing more complete dividend relief, such an approach would violate capital export neutrality. Portfolio investors in 
both countries would be encouraged to invest in the country providing greater dividend relief. Of course, some countries might find the capital inflow stimulated by this distortion attractive and perhaps worth the revenue loss it would entail, but those losing potential investment would probably object.

If tax rates in member countries are different, the situation can be even worse, unless all countries provide full dividend relief. (If dividend relief is complete, the corporate tax rate cannot matter, except for retained earnings.) Suppose that all countries in the E.E.C. allow shareholder credits for half their corporate taxes, but that corporate tax rates differ substantially. Portfolio investment in high-tax countries would be discouraged because of the differences in aggregate taxation of distributed earnings, as well as because of those on retained earnings. The combination of unequal corporate tax rates and unequal degrees of dividend relief would create complicated counterforces about which generalization is difficult. But so far as portfolio investment is concerned it appears essential to the success of any effort toward harmonization that effective corporate tax rate and the extent of dividend relief be similar across countries.

\section{B. Direct investment}

Because the draft directive's approach for direct investment is based on exemption for foreign-source income that is not distributed by the parent, rather than on the use of a foreign tax credit, it is more nearly consistent with capital-import neutrality than with capital-export neutrality. Of course, if all income were distributed by subsidiaries and 
redistributed by parents and all countries allowed full relief from double taxation of dividends, capital-export neutrality would be achieved. But failure to achieve capital-export neutrality would occur to the extent that income retained by either subsidiaries or parents was effectively taxed at different source-country rates. As is the case of portfolio investment, harmonization of corporate rates seems essential. Given the constraints just described an approach such as that of Section $V$ may be preferable to that outlined in the draft directive. Under it, to review, double taxation of portfolio dividends would be relieved mach as under the draft directive. But residence countries; rather than source countries, would provide dividend relief for direct investment. Besides requiring more complete crediting of foreign taxes, this approach would require that précompte not be levied when foreignsource income is distributed by the parent firm. 33

VII. EUROPEAN RELATIONS WITH THE UNITED STATES

If the United States decided to adopt dividend relief, it would need to work out new international fiscal relations with other countries. If those countries already allowed dividend relief, the discussion of section V would be relevant. But the U.S. would also confront countries that retained classical systems. This is, of course, basically the position in which European countries find themselves in dealing with the United States. 34 For this reason, as well as for the intrinsic independent interest of the subject, it is worthwhile to consider fiscal relations between the U.S. and Europe. 
The United States, with it classical system, is the extreme version of a country providing a low degree of dividend relief. Experience has shown that the United States will not gladly acquiesce in the denial of shareholder credits to its residents on foreign portfolio investment. But countries following common European practice (the approach outlined in the draft directive) of extending the shareholder credit for its corporate tax to American portfolio investors can expect an inflow of portfolio investment and a corresponding revenue loss. 35

So far as direct investment through European subsidiaries of American parents is concerned, there may be somewhat more latitude for negotiations, since the United States has wrung agreement to shareholder credits for dividends paid to American parents from only the United Kingdom. Here the incentives are much more lopsided than in the case of portfolio investment, for there may be a substantial revenue loss to the European treasuries, but perhaps little stimulus to capital inflow. The incentive for capital inflows to take advantage of the tax credit does not occur because much of the benefit of dividend relief accrues to the U.S. Treasury through reduced foreign tax credits, rather than to American investors. It thus seems likely that European countries are forced to continue to deny the imputation credit to direct investment from the United States even if they allow the credit to portfolio investors.

Lacking any provisions for dividend relief, the United States does not allow any imputation credits for European investors in the United States. Thus there is no corresponding revenue transfer from America to European investors or to European fiscs. And since European imputation credits are 
not allowed European portfolio investors for corporate taxes paid in America - a practice which, for good reason, no country has chosen to follow - capital export neutrality is commonly violated in Europe. But through the substitution of a foreign tax credit where exemption is presently used, capital-export neutrality could be achieved on foreign direct investment.

Given the environment in which the question is asked, there is no simple answer to whether a given European country should provide dividend relief and how mach relief it should provide. So long as the United States maintains a classical system it will be difficult for any other country to adopt a system of dividend relief that is totally satisfactory. Yet the case for dividend relief is strong, even in countries that are small and open to capital flows. 36

American intransigence on the question of mirror-image withholding rates may rule out use of the split-rate and dividend-paid deduction approaches to dividend relief. Even worse, if the United States decided to argue in treaty negotiations that failure to provide shareholder credits to American direct investors constituted a de facto withholding tax, all European countries using the imputation approach might find it necessary to renegotiate tax treaties with the United States. If the European Economic Community were to negotiate collectively, progress might be made against the American position. This appears to be appropriate since, as argued earlier, it seems that residence countries should be responsible for dividend relief on direct investment. If, 
however, a single small European country were to try to negotiate alone against the United States, it would have considerable difficulty.

Even if the American influence on the issue could be ignored, the future of dividend relief in the European Economic Community is far from clear. The primary problem is that the same amount of dividend relief is not provided in all countries. One can imagine blocs developing within the Common Market based on the extent of dividend relief allowed in various countries. Those countries providing relief from roughly half the corporate income tax on distributed earnings could agree to implement the provisions of the draft directive on a bilateral or multilateral basis. But so might other countries join with Germany in a similar arrangement based on complete relief from double taxation of dividends. 
Footnotes

*A slightly different version of this paper was prepared for a conference at Erasmus University, Rotterdam, November 24, 1978. This paper is related to NBER programs of research on Business Taxation and Finance and on International Studies and to the Bureau's special project on Capital Formation. It has not undergone review by the Board of Directors of the National Bureau of Economic Research.

$l_{\text {Throughout this paper the term "integration" is used to refer to }}$ tax schemes under which the entire income of a corporation would be attributed to shareholders and taxed to the latter at; the marginal tax rates applicable to them, whether distributed or retained. By comparison, "dividend relief" extends the concept of integration only to distributed corporate-source equity income. That is, distributed income is free of corporate tax and is taxed only to the shareholder; so far as retained earnings are concerned the corporation income tax remains a final tax, as in a classical or unintegrated system. "Dividend relief" is meant to be descriptive, rather than pejorative; it allows one to avoid such ambiguous terms as "partial integration" and the monstrous "partial partial integration," which is sometimes used to refer to systems of partial dividend relief.

${ }^{2}$ Some further definition of terms may be in order. A "classical" system is one in which corporate-source incorne is taxed to the firm and 
dividends are a component of the taxable income of shareholders; at most modest efforts are made to relieve double taxation of dividends. Under the "imputation" system the corporate income tax is treated as a withholding tax to the extent it is levied on corporate source income resulting in dividends. It is therefore imputed to the shareholder and included in his income for tax purposes; a shareholder credit is then allowed for the tax imputed to the shareholder. Under full integration, if the corporate tax is retained it is only as a withholding device. Under a "split-rate" system a lower rate is applied to distributed corporate source income than to such income which is retained. It is equivalent to a "dividend-paid deduction," under which the corporation pays tax only on income which is retained. In both of the last two systems the shareholder simply includes cash dividends in his income for tax purposes, as under the classical system. For further elaboration of these systems, see McLure (1975).

3one must, however, have considerable sympathy with the following statement from Bird(1975, p.314):

"What has been done in other countries, or what may be done there in the future, is really not very relevant to what must or should be done in the United States. References to foreign experiences, when they support a position one has adopted for other reasons are standards (sic) tactics for any good advocate; but this does not mean they are relevent. "Given the degree of observed flexibility and adaptability which the international economy has demonstrated in recent years, any argument that a minor change in tax structure will have a major or irreversible impact on international capital flows does not carry much weight. In this, as in other areas, the United States is more or less free to make its own mistakes."

${ }^{4}$ For a discussion of the supposed advantages and disadvantages of integration and dividend relief, see McLure (forthcoming, 1979 chapter 2). 
On the administrative feasibility of integration and dividend relief, see McLure (forthcoming, 1979, Chapter 5) and, for a more condensed summary, McLure (1978).

5 For an excellent exposition of the administrative difficulties of integration and dividend relief dating from the early post-war period, see Goode $(1946)$

${ }^{6}$ It is sometimes thought that the distributional and neutrality advantages of full integration could be achieved without incurring the substantial administrative burden involved in integration if dividend relief were combined with a reduction of the top personal tax rate to the level of the corporate rate. According to this argument, no shareholder would have a tax incentive to prefer retained earnings over dividends and most would have fiscal reasons to prefer dividends. If these incentives were strong enough, all corporate income would be distributed and therefore taxed only at the marginal tax rates of individuals, as under full integration. There are, however, several flaws in this argument. First, one important attraction of full integration, neutrality toward corporate financial policy, would be sacrificed. Second, if tax preferences were treated as in Europe (assumed to be the last element of income distributed but subject to a supplementary tax on distribution), it is most unlikely that distribution of corporate source-income would be complete, because the cost of dividends in terms of sacrificed retained earnings would be too high. Third, if dividend relief is partial, rather than complete, the incentives to distribution just described might not be strong enough to insure complete payout. 
7 Tax preferences can be defined as any provisions which reduce tax liability to less than it would be if the standard corporate tax rate were applied to economic income of the corporation. Preferences can be deductions which artificially reduce taxable income to below economic income, preferential rates, and credits which further reduce tax calculated by applying actual rates to taxable income. Understanding of the European discussion of tax preferences is hindered by barriers of language and must depend in large part on descriptions provided by Gourevitch (1977).

8 For further discussion of alternative ways of treating tax preferences under integration and dividend relief, see Warren (1977) and McLure (forthcoming, 1979, Chapter 4).

9 For a more detailed discussion of these political cross-currents see McLure and Surrey (1977).

10For more detailed descriptions, see Ault (1976), Ault (1977), Hammer (1975), OECD (1973), Sato and Bird (1975), Snoy (1975), and McLure (forthcoming, 1979, chapter 3 ).

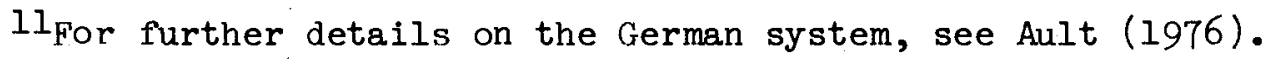

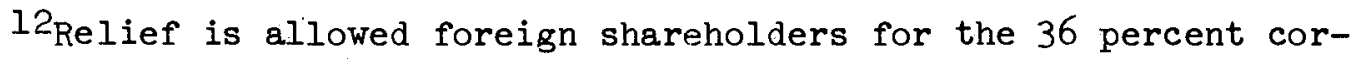
porate tax so far as it is foreign source income that is distributed.

${ }^{13}$ The American foreign tax credit does not extend to German tax attributed to income retained by the German subsidiary because under United States law tax on such income is deferred until dividends are paid.

${ }^{14} \mathrm{Germany}$ was unsuccessful in negotiating such a provision with the United States, which demanded reciprocal 15 percent withholding rates. The 
United States does, however, allow application of the 25 percent rate where profits of German subsidiaries distributed to American parents are reinvested in Germany, in order to prevent the "Auslaendereffekt". This effect occurs when dividends paid to foreigners, being taxed at the preferential German rate on distributed income and then reinvested in Germany, are subject to lower taxation than income retained by a German corporation. For further discussion of this effect see Biehl and Juettemeier (1976).

15In fact, dividends paid from income earned more than four years earlier are treated as preference income.

It may be worthwhile to point out an important definitional question which arises if dividend relief is not complete. In the German system nullification of tax preferences is unambiguous. The supplementary tax brings the effective tax rate paid on all distributed preference income up to the statutory 36 percent rate applied to ordinary taxable corporate income and allowed as a shareholder credit. Under the French system of partial dividend relief the précompte equals the shareholder credit, but not the rate of tax levied on ordinary corporate income. Thus in France preferences are nullified in the sense that no credit is given for taxes not paid; but they are not nullified in that they are not taxed like ordinary income.

16 The income used to pay the tax on distributed earnings was subject to the tax on retained income. Because of this "shadow effect" the total rate of tax applied to income resulting in dividends was actually 23.5 percent. 
Dividend income received from subsidiaries was exempt to the parent firm, if it was redistributed by the parent. If such income was retained by the parent a 36 percent supplementary tax called the "Nachsteuer" was levied to bring the total rate of tax up to the 51 percent rate applied to retentions.

17See Neumark Report (1963), van den Tempel (1970), and Commission of the European Communities (1975).

${ }^{18}$ If the shareholder credit in the nation of the distributing parent firm exceeded the credit for taxes paid to the country of residence of the subsidiary, précompte or ACT would be collected from the parent; if, on the other hand, the credit available from the source country exceeded that allowed shareholders, no adjustment would be made.

19 These conditions are, of course, not actually met. But it is fairly certain that satisfying the conditions for neutrality described below would produce higher welfare for the target group than would a tax system involving substantial distortions. Beyond that, various concepts of neutrality have advocates whose support is not conditional upon satisfaction of the conditions for welfare maximization.

20 The requirement that foreign tax credit be allowed for foreign taxes is totally unrealistic in the case of portfolio investment. For a discussion of several reasons why foreign tax credits may not result in capital export neutrality, even in the case of direct parent-subsidiary investment, see Hufbauer (1975). For a further discussion of neutrality in international fiscal relations, see Musgrave (1969). At this point we abstract from benefits of public services rendered to corporations. 
Strictly speaking, the argument in the text and those which follow apply only to the extent that taxes exceed the value of public services provided to corporations.

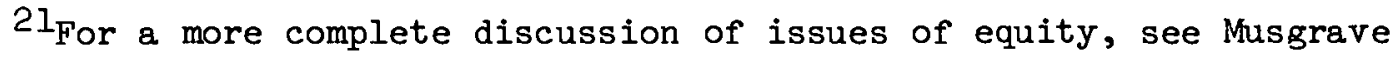
and Musgrave (1972).

${ }^{22}$ See Sato and Bird (1975).

23 The discussion in the remainder of the paper relies heavily on Ault (1978) and McLure (forthcoming, chapter 6).

${ }^{24}$ Complete capital-export neutrality would be achieved only if retained corporate earnings were taxed identically in the two countries. 25It is assumed that under the imputation method a précompte would be used if preferences were to be washed out; for the reasons, which are even more compelling in the present case, see McLure (forthcoming, 1979, Chapter 4,) and McLure (1978).

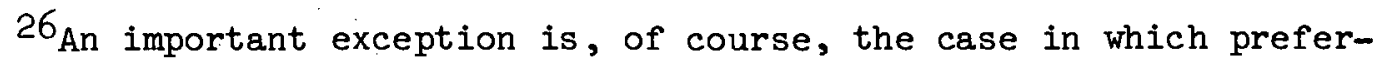
ences are stacked last and no dividends are deemed to be paid from preference income. Given the assumed difference in treatment of preference income and the implied incentives to retain and distribute preference income, it is unlikely that preference income would, in fact, be left equally untouched by distribution policy in the two countries. For more on these incentives, see McLure (forthcoming, 1979, Chapter 4).

2TThis argument can, of course, be turned around in the case of both countries passing preferences through. In that case retained earnings will generally be taxed differently in the two countries. This helps to emphasize how deficient an analysis of capital-export neutrality is if 
it ignores the treatment of retained earnings. But any system short of full integration in all countries is generally doomed to be non-neutral. 28 For further elaboration, see McLure (forthcoming, chapter 5) and Sato and Bird (1975).

${ }^{29}$ Such withholding taxes, together with the corporate tax, should be governed by "effective reciprocity" in the opinion of Sato and Bird (1975).

30 It is assumed here that the country of residence of the parent would require reporting of profits without benefit of foreign tax preferences.

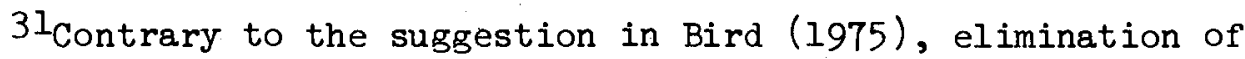
deferral would not produce capital-export neutrality if preferences of the subsidiary and those applicable to the parents' domestic income were treated differently.

32 It seems likely that the currently common practice of washing out tax preferences on distribution would continue, since it is sanctioned by the draft directive and there appears to be no tendency to deviate from it. Of course, differences in preferences could still distort the allocation of capital within the E.E.C., even if they were available only on retained earnings. These differences can be subsumed under differences in corporate rates, to be discussed below.

33 For an assessment that agrees in part with that presented here see Bird (1975, p. 313).

${ }^{34}$ Among the reasons the analogy is not total are a) Europe is facing a large country with a classical system; the U.S. would not; b) its past 


\section{(43)}

treaties tend to lock the U.S. into an inflexible position on reciprocity and non-discrimination; other countries with classical systems would probably have more lattitude.

35 This capital inflow might be small, given American reluctance to make foreign portfolio investments.

36 This view may appear to be inconsistent with that expressed, for example, in McLure (1978), that dividend relief may appropriately be delayed until administrative problems are resolved. Among the differences that account for this apparent inconsistency are a) the United States is not involved in an economic community with countries providing dividend relief and b) tax preferences are said to be less prevalent in Europe than in the United States. 

References

Ault, Hugh J., "Germany: The New Corporation Tax System," Intertax, $1976 / 8$, pp. 262-75.

Ault, Hugh J., "International Issues in Corporate Tax Integration," Law and Policy in International Business, vol. 10, no. 2 $(1978)$, pp. 461-94.

Biehl, Dieter and Juettemeier, Karl-Heinz, "German Experience with an Integrated Corporate Shareholder Tax System," a report to the Office of Tax Analysis, U.S. Treasury Department, 1976.

Bird, Richard M., "International Aspects of Integration," National Tax Journal," Vol.28 (Septemebr 1975), pp.302-14.

Commission of the European Communities, "Proposal for a Directive of the Council Concerning the Harmonization of Company Taxation and of Witholding Taxes on Dividends," reproducted in European Taxation, Vol.16 (February-April, 1976), pp.52-121.

Goode, Richard, The Postwar Corporation Tax Structure (Washington: U.S. Government Printing Office, 1946).

Gourevitch, Harry G., Integration of Corporate and Shareholder Taxes on Income: The European Experience (Washington: U.S. Government Printing Office, 1977).

Hammer, Richard M.,. "The Taxation of Income from Corporate Shareholders: Review of Present Systems in Canada, France, Germany, Japan, and the U.K.," National Tax Journal, vol. 28 (September 1975), pp. $315-34$.

Hufbauer, G.C., "A Guide to Law and Policy," in Hufbauer et al., U.S. Taxation of American Business Abroad: An Exchange of Views (Washington: American Enterprise Institute, 1975), pp. 1-6.

McLure, Charles E., Jr., "Integration of the Personal and Corporate Income Taxes: The Missing Element in Recent Tax Reform Proposals," Harvard Law Review, vol. 88 (January 1975), pp. 532-82.

Mclure, Charles E.,.Jr., "A Status Report on Tax Integration in the United States," National Tax Journal, Vol. 31 (December 1978).

McLure, Charles E., Jr., "Integration of the Income Taxes: Why and How," Journal of Corporate Taxation, vol. 2 (Winter 1976), pp. 429-64. 
McLure, Charles E., Jr., Can Corporate Income be Taxed Once? (Washington: The Brooking Institution, 1979).

McLure, Charles E., Jr. and Surrey, Stanley S., "Integration of Corporation and Individual Income Taxes: Issues for Debate," Harvard Business Review, vol. 55 (September-October 1977), pp. 169-81.

Musgrave, Peggy B., United States Taxation of Foreign Investment Income (Cambridge, Mass.: Harvard Law School International Tax Program, 1969).

Organisation for Economic Co-operation and Development (OECD), Company Tax Systems in OECD Member Countries (Paris: OECD, 19T3).

Report of the Fiscal and Financial Committee (Neumark Committee)," The EEC Reports on Tax Harmonization (Amsterdam: International Bureau for Fiscal Documentation, 1963).

Royal Commission on Taxation, Report (Ottawa: Queen's Printer, 1966).

Sato, Mitsuo and Bird, Richard M., "International Aspects of the Taxation of Corporations and Shareholders," International Monetary Fund Staff Papers, vol. 22 (July 1975), pp. 384-455.

Simon, William E., Testimony Before the House Ways and Means Committee, July 31, 1975.

Snoy, Bernard, Taxes on Direct Investment Income in the EEC: A Legal and Economic Analysis (New York: Praeger, 1975)

Ullman, Al, Congressional Record, House, 95th Congress, Second Session, February 2, 1978, pp. H640-42 and March 22, 1978, pp. H2337-38.

U.S. Department of the Treasury, Blueprints for Basic Tax Reform (Washington: U.S. Government Printing Office, 1976).

Warren, Alvin C., Jr., "Integration of the Individual and Corporate Income Taxes," a paper presented to an ALI-ABA conference on federal tax simplification, Warrenton, Virginia, January 1978.

van den Tempel, A.J., Corporation Tax and Individual Income Tax in the European Communities (Brussels: Commission of the European Communities, 1970). 